\title{
Reactions of Diiron $\mu$-Aminocarbyne Complexes Containing Nitrile Ligands
}

\author{
Luigi Busetto*, Fabio Marchetti, Stefano Zacchini and Valerio Zanotti
}

Dipartimento di Chimica Fisica ed Inorganica, Universita' di Bologna, Viale Risorgimento 4, I-40136 Bologna, Italy

\begin{abstract}
O ligante acetonitrila nos complexos $\mu$-aminocarbinos $\left[\mathrm{Fe}_{2}\{\mu-\mathrm{CN}(\mathrm{Me}) \mathrm{R}\}(\mu-\mathrm{CO})(\mathrm{CO})(\mathrm{NCMe})\right.$ $\left.(\mathrm{Cp})_{2}\right]\left[\mathrm{SO}_{3} \mathrm{CF}_{3}\right]\left(\mathrm{R}=\mathrm{Me}, \mathbf{2 a}, \mathrm{CH}_{2} \mathrm{Ph}, \mathbf{2 b}, \mathrm{Xyl}, \mathbf{2 c}\right)\left(\mathrm{Xyl}=2,6-\mathrm{Me}_{2} \mathrm{C}_{6} \mathrm{H}_{3}\right)$ é facilmente deslocado por haletos e cianetos, resultando na formação das espécies neutras $\left[\mathrm{Fe}_{2}\{\mu\right.$-CN(Me)R $\}(\mu$ $\left.\mathrm{CO})(\mathrm{CO})(\mathrm{X})(\mathrm{Cp})_{2}\right](\mathrm{X}=\mathrm{Br}, \mathrm{I}, \mathrm{CN})$. Os complexos 2 sofrem desprotonação e rearranjo da $\mathrm{MeCN}$ coordenada quando tratados com reagentes organolítio. A trimetilacetonitrila, a qual não contém hidrogênios $\alpha$ ácidos foi usada no lugar da MeCN para formar os complexos $\left[\mathrm{Fe}_{2}\{\mu-\mathrm{CN}(\mathrm{Me}) \mathrm{R}\}(\mu\right.$ $\left.\mathrm{CO})(\mathrm{CO})\left(\mathrm{NCCMe}_{3}\right)(\mathrm{Cp})_{2}\right]\left[\mathrm{SO}_{3} \mathrm{CF}_{3}\right](\mathbf{7 a - c})$. As tentativas de substituição do ligante nitrila no composto 3 por nucleófilos R (através da reação com RLi) foram frustradas e levaram à formação de produtos de decomposição. Entretanto, a reação do composto $7 \mathbf{c}$ com $\mathrm{LiC} \equiv \mathrm{CTol}\left(\mathrm{Tol}=\mathrm{C}_{6} \mathrm{H}_{4} \mathrm{Me}\right)$, seguida pelo tratamento com $\mathrm{HSO}_{3} \mathrm{CF}_{3}$, resultou na formação do complexo imino $\left[\mathrm{Fe}_{2}\{\mu\right.$ $\left.\mathrm{CN}(\mathrm{Me}) \mathrm{Xyl}\}(\mu-\mathrm{CO})(\mathrm{CO})\left\{\mathrm{N}(\mathrm{H}) \mathrm{C}\left(\mathrm{C} \equiv \mathrm{CC}_{6} \mathrm{H}_{4} \mathrm{Me}-4\right) \mathrm{CMe}_{3}\right\}(\mathrm{Cp})_{2}\right]\left[\mathrm{SO}_{3} \mathrm{CF}_{3}\right](\mathbf{8})$, o qual foi obtido via adição de acetileto à $\mathrm{NCCMe}_{3}$ coordenada.
\end{abstract}

The acetonitrile ligand in the $\mu$-aminocarbyne complexes $\left[\mathrm{Fe}_{2}\{\mu-\mathrm{CN}(\mathrm{Me}) \mathrm{R}\}(\mu\right.$ $\left.\mathrm{CO})(\mathrm{CO})(\mathrm{NCMe})(\mathrm{Cp})_{2}\right]\left[\mathrm{SO}_{3} \mathrm{CF}_{3}\right]\left(\mathrm{R}=\mathrm{Me}, \mathbf{2 a}, \mathrm{CH}_{2} \mathrm{Ph}, \mathbf{2 b}, \mathrm{Xyl}, \mathbf{2} \mathbf{c}\right)\left(\mathrm{Xyl}=2,6-\mathrm{Me}_{2} \mathrm{C}_{6} \mathrm{H}_{3}\right)$ is readily displaced by halides and cyanide anions affording the corresponding neutral species $\left[\mathrm{Fe}_{2}\{\mu\right.$ $\left.\mathrm{CN}(\mathrm{Me}) \mathrm{R}\}(\mu-\mathrm{CO})(\mathrm{CO})(\mathrm{X})(\mathrm{Cp})_{2}\right](\mathrm{X}=\mathrm{Br}, \mathrm{I}, \mathrm{CN})$. Complexes 2 undergo deprotonation and rearrangement of the coordinated $\mathrm{MeCN}$ upon treatment with organolithium reagents. Trimethylacetonitrile, that does not contain acidic $\alpha$ hydrogens has been used in place of MeCN to form the complexes $\left[\mathrm{Fe}_{2}\{\mu\right.$-CN(Me)R $\left.\}(\mu-\mathrm{CO})(\mathrm{CO})\left(\mathrm{NCCMe}_{3}\right)(\mathrm{Cp})_{2}\right]\left[\mathrm{SO}_{3} \mathrm{CF}_{3}\right](\mathbf{7 a - c})$. Attempts to replace the nitrile ligand in $\mathbf{3}$ with carbon nucleophiles (by reaction with $\mathrm{RLi}$ ) failed, resulting in decomposition products. However the reaction of $7 \mathbf{c}$ with $\mathrm{LiC} \equiv \mathrm{CTol}\left(\mathrm{Tol}=\mathrm{C}_{6} \mathrm{H}_{4} \mathrm{Me}\right)$, followed by treatment with $\mathrm{HSO}_{3} \mathrm{CF}_{3}$, yielded the imino complex $\left[\mathrm{Fe}_{2}\{\mu-\mathrm{CN}(\mathrm{Me}) \mathrm{Xyl}\}(\mu-\mathrm{CO})(\mathrm{CO})\right.$ $\left.\left\{\mathrm{N}(\mathrm{H}) \mathrm{C}\left(\mathrm{C} \equiv \mathrm{CC}_{6} \mathrm{H}_{4} \mathrm{Me}-4\right) \mathrm{CMe}_{3}\right\}(\mathrm{Cp})_{2}\right]\left[\mathrm{SO}_{3} \mathrm{CF}_{3}\right](8)$, obtained via acetilyde addition at the coordinated $\mathrm{NCCMe}_{3}$.

Keywords: acetonitrile, nitrile activation, carbyne complexes, dinuclear complexes, C-C bond formation

\section{Introduction}

The formation of C-C bonds in dinuclear transition metal complexes, by coupling reactions of coordinated hydrocarbon ligands, attracts considerable attention because these reactions can act as models for the surface species involved in heterogeneously catalyzed processes. ${ }^{1}$ Among the complexes studied, those containing $\mu$ methylidene and $\mu$-methylidyne ligands are of particular interest since they are supposed to play an important role in the Fischer -Tropsch processes. ${ }^{2}$

In recent years we have found that the formation of C$\mathrm{C}$ bond in bridging aminocarbyne complexes $\left[\mathrm{Fe}_{2}\{\mu\right.$ -

\footnotetext{
* e-mail: busetto@ms.fci.unibo.it
}

$\left.\mathrm{CN}(\mathrm{Me}) \mathrm{R}\}(\mu-\mathrm{CO})(\mathrm{CO})_{2}(\mathrm{Cp})_{2}\right]\left[\mathrm{SO}_{3} \mathrm{CF}_{3}\right]\left(\mathrm{R}=\mathrm{Me}, \mathbf{1 a} ; \mathrm{CH}_{2} \mathrm{Ph}\right.$; 1b; $\mathrm{Xyl}, \mathbf{1 c})\left(\mathrm{Xyl}=2,6-\mathrm{Me}_{2} \mathrm{C}_{6} \mathrm{H}_{3}\right)$ can be achieved by addition of carbon nucleophiles ( $\mathrm{R}^{\prime-}$ ) which occurs selectively at different ligands: organocuprates and acetylides attack the carbonyl carbon to form the acyl complexes $\left[\mathrm{Fe}_{2}\{\mu\right.$-CN(Me)R $\left.\}(\mu-\mathrm{CO})(\mathrm{CO})\left(\mathrm{COR}^{\prime}\right)(\mathrm{Cp})_{2}\right]$, whereas organolithium or Grignard reagents give preferentially addition to the $\mathrm{C}_{5} \mathrm{H}_{5}$ ring yielding the dienyl complexes $\left[\mathrm{Fe}_{2}\{\mu\right.$-CN(Me)R $\left.\}(\mu-\mathrm{CO})(\mathrm{CO})_{2}(\mathrm{Cp})\left(\mathrm{C}_{5} \mathrm{H}_{5} \mathrm{R}^{\prime}\right)\right] .{ }^{3}$

Surprisingly, none of the above nucleophilic additions involve the $\mu$-C of the aminocarbyne ligand, which appears rather unreactive, particularly if compared with the powerful electrophilic character of the $\mu$-methylidyne carbon in the related complex $\left[\mathrm{Fe}_{2}(\mu-\mathrm{CH})(\mu-\mathrm{CO})(\mathrm{CO})_{2}\right.$ $\left.(\mathrm{Cp})_{2}\right]^{+} .{ }^{4}$ Only cyanide (from $\mathrm{NBu}_{4} \mathrm{CN}$ ) has been found to react at the carbyne carbon to yield the aminocarbene 
complex $\left[\mathrm{Fe}_{2}\{\mu-\mathrm{C}(\mathrm{CN}) \mathrm{N}(\mathrm{Me}) \mathrm{R}\}(\mu-\mathrm{CO})(\mathrm{CO})_{2}(\mathrm{Cp})_{2}\right]{ }^{5} \mathrm{~A}$ possible explanation for such inertness resides in the strong $\pi$-interaction between nitrogen and the carbyne carbon, which suggests a large contribution of the $\mu$-iminium structure $\left(\mu\right.$-C=NRR'). ${ }^{6}$

The bridging methylidene ligand in $\left[\mathrm{Ru}_{2}\left(\mu-\mathrm{CH}_{2}\right)(\mu\right.$ $\left.\mathrm{CO})(\mathrm{CO})_{2}(\mathrm{Cp})_{2}\right]$ is also rather unreactive. However the corresponding acetonitrile complex $\left[\mathrm{Ru}_{2}\left(\mu-\mathrm{CH}_{2}\right)(\mu\right.$ $\left.\mathrm{CO})(\mathrm{CO})(\mathrm{NCR})(\mathrm{Cp})_{2}\right]$ has been found to undergo $\mathrm{C}-\mathrm{C}$ coupling reactions with unsaturated hydrocarbons and diazoalkanes, ${ }^{7}$ demonstrating that the presence of a labile ligand is crucial for allowing coordination of hydrocarbyl fragments, and promoting their intramolecular coupling with the $\mu-\mathrm{CH}_{2}$.

In the light of these considerations, we decided to investigate the reactivity of diiron aminocarbyne complexes containing a nitrile ligand, towards nucleophiles, including carbon nucleophiles, with the aim of testing the possibility of $\mathrm{C}-\mathrm{C}$ bond formation.

\section{Results and Discussion}

A terminal carbonyl ligand in $\left[\mathrm{Fe}_{2}\{\mu-\mathrm{CN}(\mathrm{Me}) \mathrm{R}\}(\mu\right.$ $\left.\mathrm{CO})(\mathrm{CO})_{2}(\mathrm{Cp})_{2}\right]\left[\mathrm{SO}_{3} \mathrm{CF}_{3}\right]$ 1a-c is readily displaced by $\mathrm{MeCN}$ upon treatment with $\mathrm{Me}_{3} \mathrm{NO}$ in refluxing acetonitrile, affording $\left[\mathrm{Fe}_{2}\{\mu\right.$-CN(Me)R $\}(\mu$-CO)(CO)(NCMe) $\left.(\mathrm{Cp})_{2}\right]\left[\mathrm{SO}_{3} \mathrm{CF}_{3}\right]\left(\mathrm{R}=\mathrm{Me}, \mathbf{2 a} ; \mathrm{CH}_{2} \mathrm{Ph} ; \mathbf{2} \mathbf{b} ; \mathrm{Xyl}, \mathbf{2 c}\right){ }^{8}$ Nitrilecontaining complexes have been often considered equivalent to the co-ordinatively unsaturated species because of the substitution lability that nitrile ligands usually exhibit. ${ }^{9}$ As expected, the complexes 2a-c undergo displacement of $\mathrm{MeCN}$ by a variety of ligands which include phosphines, isocyanides, halides and cyanides. Most of these substitution reactions have been previously described..$^{8,10}$ In the experimental part are given details of the preparation and spectroscopic properties of the novel halide complexes $\left[\mathrm{Fe}_{2}\{\mu\right.$-CN(Me)Xyl $\}(\mu-\mathrm{CO})(\mathrm{CO})(\mathrm{X})$ $\left.(\mathrm{Cp})_{2}\right](\mathrm{X}=\mathrm{Br}, \mathbf{3 a} ; \mathrm{I}, \mathbf{3 b})$, Scheme 1.

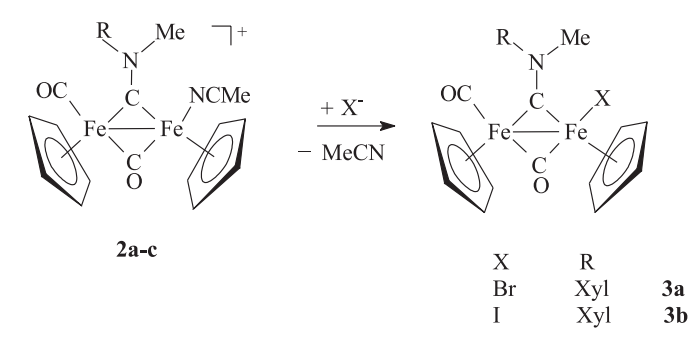

Scheme 1.

The spectroscopic properties of $\mathbf{3 a}$ are similar to those of the chloride complex $\left[\mathrm{Fe}_{2}\{\mu\right.$-CN(Me)Xyl $\}(\mu-\mathrm{CO})(\mathrm{CO})$
$(\mathrm{Cl})(\mathrm{Cp})_{2}$ ] previously reported. ${ }^{8}$ Both chloride and bromide complexes show the presence, in $\mathrm{CDCl}_{3}$ solution, of only the $c i s$ isomer as usually found in di-iron $\mu$-aminocarbyne complexes $^{3,11}$ (cis and trans are referred to the mutual position of the $\mathrm{Cp}$ rings with respect to the $\mathrm{Fe}-\mathrm{Fe}$ bond). By contrast, the iodide complex $\mathbf{3 b}$ consists of both cis and trans isomers, possibly due to bulkiness of the iodide ligand.

The reactions of $\mathbf{2 a - c}$ with cyanide illustrate well the change in the reactivity pattern induced by the presence of the acetonitrile ligand. In fact, whereas the addition of cyanide occurs at the carbyne carbon of 1a-c to form the alkylidene compounds $\left[\mathrm{Fe}_{2}\{\mu-\mathrm{C}(\mathrm{CN}) \mathrm{N}(\mathrm{Me}) \mathrm{R}\}(\mu\right.$ $\left.\mathrm{CO})(\mathrm{CO})_{2}(\mathrm{Cp})_{2}\right](\mathbf{4 a - c}),{ }^{5}$ the corresponding acetonitrile complexes $\left[\mathrm{Fe}_{2}\{\mu\right.$-CN $\left.(\mathrm{Me}) \mathrm{R}\}(\mu-\mathrm{CO})(\mathrm{CO})(\mathrm{NCMe})(\mathrm{Cp})_{2}\right]$ [ $\left.\mathrm{SO}_{3} \mathrm{CF}_{3}\right](2 \mathrm{a}-\mathrm{c})$ react with $\mathrm{CN}^{-}$leading to the formation of $\left[\mathrm{Fe}_{2}\{\mu\right.$-CN(Me)R $\left.\}(\mu-\mathrm{CO})(\mathrm{CO})(\mathrm{CN})(\mathrm{Cp})_{2}\right]($ 5a-c) $($ Scheme $2)^{8}$

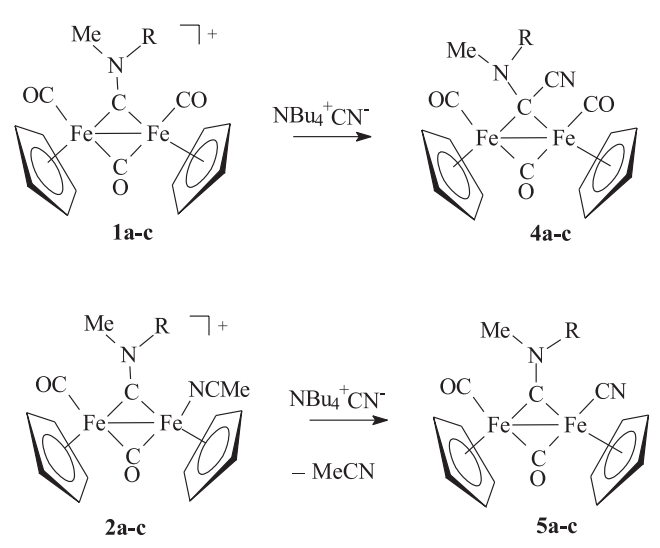

Scheme 2.

The MeCN ligand in 2a-c seems therefore able to direct selectively the nuclephilic attack at the metal atom. In order to determine whether this would apply to carbon nucleophiles such as organolithium or organocopper reagents, the reactions of $\mathbf{2 a - c}$ with LiR were studied. The results reported in Scheme 3 show that organolithium reagents (including less basic lithium acetylides) behave towards 2a-c like strong bases rather than nucleophiles, leading to the deprotonation of the coordinated $\mathrm{MeCN}$ instead of giving its displacement, and yielding the cyano methyl complexes $\left[\mathrm{Fe}_{2}\{\mu\right.$-CN $(\mathrm{Me}) \mathrm{R}\}(\mu-\mathrm{CO})(\mathrm{CO})\left(\mathrm{CH}_{2} \mathrm{CN}\right)$ $\left.(\mathrm{Cp})_{2}\right](\mathbf{6 a}-\mathbf{c}) .{ }^{12}$ Proton abstraction from coordinated acetonitrile is not surprising, and its enhanced acidity has been exploited to catalyse $\mathrm{MeCN}$ condensation with carbonyl compounds. ${ }^{13}$ However the rearrangement to cyanomethyl ligand is rather unusual and has been previously observed only in the case of $\left[\mathrm{RhOs}\left(\mathrm{CH}_{2} \mathrm{CN}\right)\right.$ $\left.(\mathrm{CO})_{3}(\mathrm{dppm})_{2}\right] .^{14}$ 


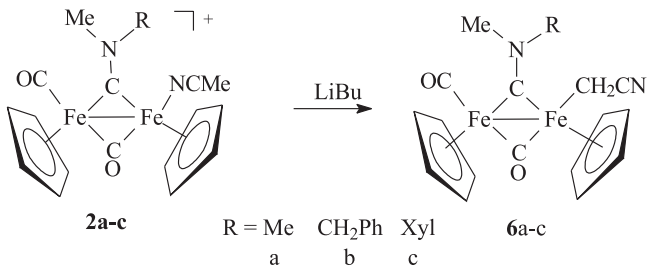

Scheme 3.

Since the acetonitrile ligand in compounds $2 \mathbf{a}-\mathbf{c}$ can not be displaced by organolithium reagents, we have examined the synthesis and reactivity of diiron complexes containing trimetylacetonitrile in place of $\mathrm{MeCN}$. The absence of acidic $\alpha-\mathrm{C}-\mathrm{H}$ in $\mathrm{NCCMe}_{3}$ should allow the treatment with carbon nucleophiles, providing access to dinuclear complexes with hydrocarbyl ligands of the type $\left[\mathrm{Fe}_{2}\{\mu-\mathrm{CN}(\mathrm{Me}) \mathrm{R}\}(\mu-\mathrm{CO})(\mathrm{CO})\left(\mathrm{R}^{\prime}\right)(\mathrm{Cp})_{2}\right],\left(\mathrm{R}^{\prime}=\right.$ alkyl, aryl, vinyl or alkynyl).

The synthesis and the spectroscopic properties of the trimethylacetonitrile complexes $\left[\mathrm{Fe}_{2}\{\mu-\mathrm{CN}(\mathrm{Me}) \mathrm{R}\}(\mu\right.$ $\left.\mathrm{CO})(\mathrm{CO})\left(\mathrm{NCCMe}_{3}\right)(\mathrm{Cp})_{2}\right]\left[\mathrm{SO}_{3} \mathrm{CF}_{3}\right]\left(\mathrm{R}=\mathrm{Me}, 7 \mathrm{a} ; \mathrm{CH}_{2} \mathrm{Ph}\right.$; $\mathbf{7 b}$; Xyl, 7c) parallel those of $\mathbf{2 a - c}$. They have been obtained upon treatment of 1a-c with a slight excess of $\mathrm{Me}_{3} \mathrm{CCN}$ in THF solution in the presence of $\mathrm{Me}_{3} \mathrm{NO}$.

The IR spectra of 7a-c, in $\mathrm{CH}_{2} \mathrm{Cl}_{2}$ solution, exhibit one terminal and one bridging carbonyl absorption (e.g. at 1982 and $1815 \mathrm{~cm}^{-1}$ for $\left.7 \mathbf{a}\right)$. The ${ }^{1} \mathrm{H}$ and ${ }^{13} \mathrm{C}$ NMR spectra show two signals of the same intensity for the nonequivalent $\mathrm{Cp}$ groups (for 7a at $\delta$ 5.01, 4.85 and 89.0 87.5, respectively). Likewise each of the $\mathrm{N}$-bonded methyl groups in $\mathbf{7 a}$ gives rise to a singlet resonance. The NMR spectra of $\mathbf{7 b}$, which contain the asymmetrically substituted $\mu-\mathrm{C}=\mathrm{N}(\mathrm{Me})\left(\mathrm{CH}_{2} \mathrm{Ph}\right)$ show the presence of two isomers in solution. These isomeric forms, which are usually found in complexes of the type $\left[\mathrm{Fe}_{2}\{\mu-\mathrm{CN}(\mathrm{Me}) \mathrm{R}\}(\mu-\mathrm{CO})(\mathrm{CO})\right.$ $\left.(\mathrm{L})(\mathrm{Cp})_{2}\right]$ and indicated as $\alpha$ and $\beta$ isomers, ${ }^{3,10,11,15}$ are due to the different orientations of $\mathrm{R}$ and $\mathrm{Me}$ with respect to the non equivalent $\mathrm{Fe}$ atoms (Figure 1). Compound 7c consists of only one of the two possible $\alpha$ and $\beta$ isomers. This is presumably due to the steric demand of the Xyl group, compared to $\mathrm{Me}$, which inhibits the formation of more hindered isomer. It should be reminded that interconvertion of the $\alpha$ and $\beta$ isomers via rotation around the $\mu-\mathrm{C}-\mathrm{N}$ bond is not possible due to the double bond character of this interaction.

The ${ }^{13} \mathrm{C}$ NMR spectra of 7a-c, exhibit the characteristic low field signal of the bridging carbyne carbon (e.g. at $\delta$ 339.0 for $7 \mathbf{c}$ ).

The reactions of $\left[\mathrm{Fe}_{2}\{\mu-\mathrm{CN}(\mathrm{Me}) \mathrm{Xyl}\}(\mu-\mathrm{CO})(\mathrm{CO})\right.$ $\left.\left(\mathrm{NCCMe}_{3}\right)(\mathrm{Cp})_{2}\right]\left[\mathrm{SO}_{3} \mathrm{CF}_{3}\right]$ 7c with several organo lithium $\mathrm{RLi},(\mathrm{R}=\mathrm{Me}, \mathrm{Bu}, \mathrm{C} \equiv \mathrm{CPh})$, reagents have been investigated.



Figure 1. $\alpha$ and $\beta$ isomeric forms of compounds 7 .

The expected displacement of the nitrile ligand by the carbon nucleophile does not take place and the reaction mixtures contain unidentified decomposition products. On the other hand organo-lithium reagents are also strong reducing agent and since it is known ${ }^{16}$ that the aminocarbyne complexes $\mathbf{1 b}$ can be reduced to the unstable radical $\left[\mathrm{Fe}_{2}\left\{\mu-\mathrm{CN}(\mathrm{Me}) \mathrm{CH}_{2} \mathrm{Ph}\right\}(\mu-\mathrm{CO})(\mathrm{CO})_{2}(\mathrm{Cp})_{2}\right]^{*}$, it is likely that the above reactions of $7 \mathrm{c}$ proceed through a radical mechanism. A remarkable exception to this general trend is represented by the reaction with LiCCtol: treatment of 7c with tolylacetylide, followed by addition of $\mathrm{HSO}_{3} \mathrm{CF}_{3}$ results in the formation of the imino complex $\left[\mathrm{Fe}_{2}\{\mu\right.$ $\mathrm{CN}(\mathrm{Me}) \mathrm{Xyl}\}(\mu-\mathrm{CO})(\mathrm{CO})\left\{\mathrm{N}(\mathrm{H}) \mathrm{C}\left(\mathrm{C} \equiv \mathrm{CC}_{6} \mathrm{H}_{4} \mathrm{Me}-4\right) \mathrm{CMe}_{3}\right\}$ $\left.(\mathrm{Cp})_{2}\right]\left[\mathrm{CF}_{3} \mathrm{SO}_{3}\right](\mathbf{8})$, Scheme 4.

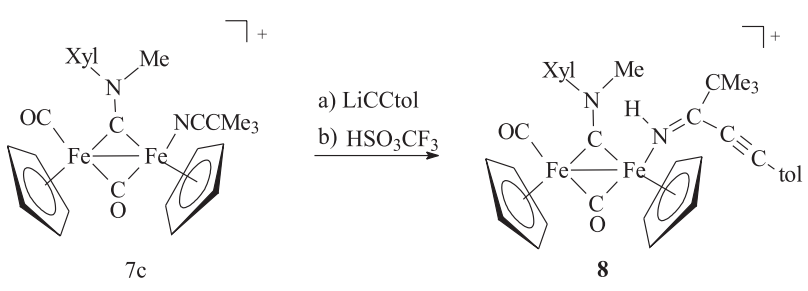

Scheme 4

Compound $\mathbf{8}$ has been characterized by elemental analyses and IR and NMR spectroscopy.

The IR spectrum, in $\mathrm{CH}_{2} \mathrm{Cl}_{2}$ solution, exhibits one terminal and one bridging carbonyl at 1977 and $1817 \mathrm{~cm}^{-1}$, respectively. Evidence of the imine coordination is given by the IR spectrum, $v(\mathrm{~N}-\mathrm{H})$ at 3314 (in $\mathrm{KBr}$ pellets) and by ${ }^{1} \mathrm{H}$ NMR resonance at $\delta 6.12$ due to the $\mathrm{N}-\mathrm{H}$ proton. Major features, in the ${ }^{13} \mathrm{C}$ NMR spectrum of $\mathbf{8}$ include the expected low-field resonance of the $\mu$-aminocarbyne carbon (at $\delta$ 340.1), which indicates that the carbyne ligand has been unaffected by the reaction, and the signal attributable to the imine carbon at $\delta 186.7$.

The formation of complex $\mathbf{8}$ is the result of a nucleophilic attack at the coordinated $\mathrm{NCCMe}_{3}$, which presumably forms the azavinylidene intermediate $\left[\mathrm{Fe}_{2}\{\mu\right.$ $\mathrm{CN}(\mathrm{Me}) \mathrm{Xyl}\}(\mu-\mathrm{CO})(\mathrm{CO})\left\{\mathrm{N}=\mathrm{C}\left(\mathrm{C} \equiv \mathrm{CC}_{6} \mathrm{H}_{4} \mathrm{Me}-4\right) \mathrm{CMe}_{3}\right\}$ $\left(\mathrm{Cp}_{2}\right)$ ] (9). In spite of the fact that several azavinylidene complexes are known, ${ }^{17}$ the intermediate $\mathbf{9}$ appears too unstable in our hands to be characterized even by 
spectroscopy. However nitrogen protonation transforms the azavinyldene into the more stable imino complex $\mathbf{8}$.

Nucleophilic addition at coordinated nitriles is not a rare occurrence, in spite of the fact that they usually behave as labile ligands. ${ }^{18}$ However additions generally involve water, alcohols, amines and only at very low extent, carbon nucleophiles with formation of imine ligands. ${ }^{19}$

Finally it should be underlined that the formation of $\mathbf{9}$ from the nitrile precursor 7c, as well as the synthesis of the cyanomethyl 6a-c, indicate that nitrile ligands are strongly activated by coordination to the diiron $\mu$-aminocarbyne frame, and that, far from behaving exclusively as labile ligands, they show a remarkable reactivity.

\section{Experimental}

\section{General}

All reactions were carried out routinely under nitrogen using standard Schlenk techniques. Solvents were distilled immediately before use under nitrogen from appropriate drying agents. Glassware was oven-dried before use. Infrared spectra were recorded on a Perkin-Elmer 983-G spectrophotometer, ${ }^{1} \mathrm{H}$ and ${ }^{13} \mathrm{C}$ NMR spectra on a Varian Gemini 300. Unless otherwise stated, NMR signals due to trace amounts of second isomeric form are italicized. All the reagents were commercial products (Aldrich) of the highest purity available and used as received. $\left[\mathrm{Fe}_{2}(\mathrm{CO})_{4}(\mathrm{Cp})_{2}\right]$ was from Strem and used as received. Compounds $\left[\mathrm{Fe}_{2}\{\mu\right.$ $\left.\mathrm{CN}(\mathrm{Me}) \mathrm{R}\}(\mu-\mathrm{CO})(\mathrm{CO})_{2}(\mathrm{Cp})_{2}\right]\left[\mathrm{SO}_{3} \mathrm{CF}_{3}\right](\mathrm{R}=\mathrm{Me} \mathbf{2 a}$ $\left.\mathrm{R}=\mathrm{CH}_{2} \mathrm{Ph} \mathbf{2 b}, \mathrm{Me}_{2} \mathrm{C}_{6} \mathrm{H}_{3} \mathbf{2 c}\right)^{3,11}$ were prepared as described in the literature.

Syntheses of $\left[\mathrm{Fe}_{2}\{\mu-\mathrm{CN}(\mathrm{Me}) \mathrm{Xyl}\}(\mu-\mathrm{CO})(\mathrm{CO})(\mathrm{Br})(\mathrm{Cp})_{2}\right]$ (3a) and $\left[\mathrm{Fe}_{2}\{\mu-C N(\mathrm{Me}) X y l\}(\mu-\mathrm{CO})(\mathrm{CO})(\mathrm{I})(\mathrm{Cp})_{2}\right](\mathbf{3 b})$

Potassium bromide (445 mg, $3.71 \mathrm{mmol}$ ) was added to a solution of $\left[\mathrm{Fe}_{2}\{\mu-\mathrm{CN}(\mathrm{Me})(\mathrm{Xyl})\}(\mu-\mathrm{CO})(\mathrm{CO})(\mathrm{NCMe})\right.$ $\left.(\mathrm{Cp})_{2}\right]\left[\mathrm{SO}_{3} \mathrm{CF}_{3}\right](\mathbf{2 c})(170 \mathrm{mg}, 0.26 \mathrm{mmol})$ in THF (15 mL) and the mixture was heated at refluxing temperature for 30 min. Removal of the solvent gave a brown residue that was chromatographed on alumina using THF and diethyl ether (1:1) as eluent. Crystallization from $\mathrm{CH}_{2} \mathrm{Cl}_{2}$ and $\mathrm{Et}_{2} \mathrm{O}$ afforded 3a (120 mg, 85\%). Analysis. Found: C, 50.41; H, $4.25 \% . \mathrm{C}_{22} \mathrm{H}_{22} \mathrm{BrFe}_{2} \mathrm{NO}_{2}$ requires: $\mathrm{C}, 50.42 ; \mathrm{H}, 4.23 \%$. IR $\left(\mathrm{CH}_{2} \mathrm{Cl}_{2}\right) v_{\max } / \mathrm{cm}^{-1}: 1979 \mathrm{vs}$ and $1797 \mathrm{~s}(\mathrm{CO}) . \mathrm{NMR}: \delta_{\mathrm{H}}$ $\left(\mathrm{CDCl}_{3}\right)$ : 7.39-7.20 (3 H, m C $\left.{ }_{6} \mathrm{H}_{4}\right), 4.90(3 \mathrm{H}, \mathrm{s}, \mathrm{NMe}), 4.75$ (5 H, s, Cp), 4.30 (5 H, s, Cp), 2.75 and $2.22\left(6 \mathrm{H}, \mathrm{s}, M e_{2} \mathrm{C}_{6} \mathrm{H}_{3}\right)$. $\delta_{\mathrm{C}}\left(\mathrm{CDCl}_{3}\right): 342.8(\mu-\mathrm{C}), 267.5(\mu-\mathrm{CO}), 214.0(\mathrm{CO}), 149.3$ (ipso- $\left.\mathrm{Me}_{2} C_{6} \mathrm{H}_{3}\right), 135.1-128.9\left(\mathrm{Me}_{2} C_{6} \mathrm{H}_{3}\right), 87.1(\mathrm{Cp}) ; 53.8$ (N-Me), 19.3 and $18.3\left(\mathrm{Me}_{2} \mathrm{C}_{6} \mathrm{H}_{3}\right)$.
Compound $\mathbf{3 b}$ was obtained from $\mathbf{2 c}$ and $\mathrm{KI}$ following the same procedure described for the synthesis of $\mathbf{3 a}$. $\mathbf{3 b}$ : (88\%). Analysis. Found: C, 46.31; H, 3.90\%. $\mathrm{C}_{22} \mathrm{H}_{22} \mathrm{Fe}_{2} \mathrm{INO}_{2}$ requires: $\mathrm{C}, 46.27 ; \mathrm{H}, 3.88 \%$. Bands and signals due to a second isomeric form (in about 0.8 ratio) are italicized. IR $\left(\mathrm{CH}_{2} \mathrm{Cl}_{2}\right) v_{\max } / \mathrm{cm}^{-1}: 1974 \mathrm{vs}, 1953 \mathrm{vs}$ and 1797s (CO). NMR $\delta_{\mathrm{H}}\left(\mathrm{CDCl}_{3}\right): 7.39-7.20\left(3 \mathrm{H}, \mathrm{m}, \mathrm{C}_{6} \mathrm{H}_{4}\right)$, 4.94, 4.82 (3 H, s, NMe), 4.77, 4.75, 4.30, 4.26, (10 H, s, $\mathrm{Cp}), 2.74,2.57,2.48$, and $2.26\left(6 \mathrm{H}, \mathrm{s}, \mathrm{Me}_{2} \mathrm{C}_{6} \mathrm{H}_{3}\right) . \delta_{\mathrm{C}}\left(\mathrm{CDCl}_{3}\right)$ : 344.1, 341.5 ( $\mu$-C), 267.9, 266.1 ( $\mu$-CO), 215.7, 214.6 (CO), $149.8,149.4$ (ipso- $\left.C_{6} \mathrm{H}_{3} \mathrm{Me}_{2}\right), 135.3-128.9\left(C_{6} \mathrm{H}_{3} \mathrm{Me}_{2}\right)$, 90.4, 88.1, 87.2, 86.9, (Cp), 55.5, 55.3 (N-Me); 19.3, 18.5 and $18.3\left(\mathrm{C}_{6} \mathrm{H}_{3} M e_{2}\right)$.

Synthesis of $\left[\mathrm{Fe}_{2}\left(\mu-\mathrm{CNMe}_{2}\right)(\mu-\mathrm{CO})(\mathrm{CO})\left(\mathrm{NCCMe}_{3}\right)(\mathrm{Cp})_{2}\right]$ $\left[\mathrm{SO}_{3} \mathrm{CF}_{3}\right](\mathrm{7a}),\left[\mathrm{Fe}_{2}\left\{\mu-\mathrm{CN}(\mathrm{Me})\left(\mathrm{CH}_{2} \mathrm{Ph}\right)\right\}(\mu-\mathrm{CO})(\mathrm{CO})\right.$ $\left.\left(\mathrm{NCCMe}_{3}\right)(\mathrm{Cp})_{2}\right]\left[\mathrm{SO}_{3} \mathrm{CF}_{3}\right](\mathbf{7 b}),\left[\mathrm{Fe}_{2}\{\mu-\mathrm{CN}(\mathrm{Me})(\mathrm{Xyl})\}(\mu-\right.$ $\left.\mathrm{CO})(\mathrm{CO})\left(\mathrm{NCCMe}_{3}\right)(\mathrm{Cp})_{2}\right]\left[\mathrm{SO}_{3} \mathrm{CF}_{3}\right](7 \mathrm{c})$

Compound 1a (320 mg, $0.60 \mathrm{mmol})$ and trimethylacetonitrile (100 mg, $1.20 \mathrm{mmol})$ in THF $(10 \mathrm{~mL})$ was treated with anhydrous $\mathrm{Me}_{3} \mathrm{NO}(45 \mathrm{mg}, 0.60 \mathrm{mmol}$ ) and the mixture was stirred for $120 \mathrm{~min}$. Filtration on a Celite pad and removal of the solvent gave a brown residue that was washed with petroleum ether (bp. 40-60 ${ }^{\circ} \mathrm{C}$ ) and crystallized from $\mathrm{CH}_{2} \mathrm{Cl}_{2}$ layered with n-pentane at $-20{ }^{\circ} \mathrm{C}$ yielding 7a as a brown microcrystalline solid (253 mg, 72\%). Analysis. Found: C, 43.31; H, $4.36 \%$. $\mathrm{C}_{21} \mathrm{H}_{25} \mathrm{~F}_{3} \mathrm{Fe}_{2} \mathrm{~N}_{2} \mathrm{O}_{5} \mathrm{~S}$ requires: $\mathrm{C}, 43.03 ; \mathrm{H}, 4.30 \%$. IR $\left(\mathrm{CH}_{2} \mathrm{Cl}_{2}\right)$ $v_{\text {max }} / \mathrm{cm}^{-1}: 1982 \mathrm{vs}$ and $1815 \mathrm{~s}(\mathrm{CO}) . \mathrm{NMR} \delta_{\mathrm{H}}\left(\mathrm{CDCl}_{3}\right): 5.01$ (5 H, s, Cp), 4.85 (5 H, s, Cp), 4.62 (3 H, s, NMe), 4.31 (3 H, $\mathrm{s}, \mathrm{NMe})$, and $1.03\left(9 \mathrm{H}, \mathrm{CMe}_{3}\right) . \delta_{\mathrm{C}}\left(\mathrm{CDCl}_{3}\right): 329.9(\mu-C)$, 267.3 ( $\mu$-CO), 211.9 (CO), $139.2\left(\mathrm{NCCMe}_{3}\right), 89.0,87.5$ (Cp), 54.2, $53.3\left(\mathrm{NMe}_{2}\right), 31.3$, and $28.2\left(\mathrm{NCCMe}_{3}\right)$.

Compounds $\mathbf{7 b}$ and $\mathbf{7 c}$ were obtained from $\mathbf{2 b}$ and $\mathbf{2 c}$, respectively, following the same procedure above described. 7b: (77\%) Analysis. Found: C, 48.91; H, $4.47 \%$. $\mathrm{C}_{27} \mathrm{H}_{29} \mathrm{~F}_{3} \mathrm{Fe}_{2} \mathrm{~N}_{2} \mathrm{O}_{5} \mathrm{~S}$ requires: $\mathrm{C}, 48.96 ; \mathrm{H}, 4.41 \%$. IR $\left(\mathrm{CH}_{2} \mathrm{Cl}_{2}\right)$ $v_{\max } / \mathrm{cm}^{-1}: 1981 \mathrm{vs}$ and $1815 \mathrm{~s}(\mathrm{CO})$. NMR ( $\alpha$ isomer): $\delta_{\mathrm{H}}$ $\left(\mathrm{CDCl}_{3}\right): 7.41-7.22\left(8 \mathrm{H}, \mathrm{m}, \mathrm{C}_{6} \mathrm{H}_{5}\right.$ and $\left.\mathrm{Me}_{2} \mathrm{C}_{6} H_{3}\right), 5.95,5.78$ ( $\left.2 \mathrm{H}, \mathrm{d}, \mathrm{J} 19 \mathrm{~Hz}, \mathrm{CH}_{2} \mathrm{Ph}\right), 4.97$ (5 H, s, Cp), 4.92 (5 H, s, Cp), $4.45(3 \mathrm{H}, \mathrm{s}, \mathrm{NMe})$, and $1.03\left(9 \mathrm{H}, \mathrm{s}, \mathrm{CMe}{ }_{3}\right) ;(\beta$ isomer $): \delta_{\mathrm{H}}$ $\left(\mathrm{CDCl}_{3}\right): 7.41-7.22\left(8 \mathrm{H}, \mathrm{m}, \mathrm{C}_{6} \mathrm{H}_{5}\right.$ and $\left.\mathrm{Me}_{2} \mathrm{C}_{6} \mathrm{H}_{3}\right), 6.42,6.36$ ( $\left.2 \mathrm{H}, \mathrm{d}, \mathrm{J} 19 \mathrm{~Hz}, \mathrm{CH}_{2} \mathrm{Ph}\right), 5.05$ (5 H, s, Cp), 4.85 (5 H, s, Cp), $4.18(3 \mathrm{H}, \mathrm{s}, \mathrm{NMe})$, and $1.03\left(9 \mathrm{H}, \mathrm{s}, \mathrm{CMe}_{3}\right) ;(\alpha: \beta$ ratio $=$ 0.9). 7c: $(89 \%)$. Analysis. Found: C, 50.01; H, $4.69 \%$. $\mathrm{C}_{28} \mathrm{H}_{31} \mathrm{~F}_{3} \mathrm{Fe}_{2} \mathrm{~N}_{2} \mathrm{O}_{5} \mathrm{~S}$ requires: $\mathrm{C}, 49.72 ; \mathrm{H}, 4.62 \%$. IR $\left(\mathrm{CH}_{2} \mathrm{Cl}_{2}\right)$ $v_{\text {max }} / \mathrm{cm}^{-1}: 1987 \mathrm{vs}$ and $1821 \mathrm{~s}(\mathrm{CO}) . \mathrm{NMR} \delta_{\mathrm{H}}\left(\mathrm{CDCl}_{3}\right): 7.42-$ $7.04\left(8 \mathrm{H}, \mathrm{m}, \mathrm{C}_{6} \mathrm{H}_{5}\right.$ and $\left.\mathrm{Me}_{2} \mathrm{C}_{6} \mathrm{H}_{3}\right), 4.98(5 \mathrm{H}, \mathrm{s}, \mathrm{Cp}), 4.47$ (5 $\mathrm{H}, \mathrm{s}, \mathrm{Cp}), 4.78$ (3 H, s, NMe), 2.68, 2.14 (6 H, s, Me $\mathrm{C}_{6} \mathrm{H}_{3}$ ), and $1.11\left(9 \mathrm{H}, \mathrm{CMe}_{3}\right) . \delta_{\mathrm{C}}\left(\mathrm{CDCl}_{3}\right): 339.0(\mu-C), 265.2(\mu-$ 
$\mathrm{CO}), 212.5$ (CO), $148.8\left(\mathrm{NCCMe}_{3}\right), 141.1-129.7\left(\mathrm{Me}_{2} \mathrm{C}_{6} \mathrm{H}_{3}\right)$, 88.8, 88.4 (Cp), 56.1 (NMe), 31.5, 28.3 ( $\left.\mathrm{NCCMe}_{3}\right), 19.5$ and $18.2\left(\mathrm{Me}_{2} \mathrm{C}_{6} \mathrm{H}_{3}\right)$.

Synthesis of $\left[\mathrm{Fe}_{2}\{\mu-\mathrm{CN}(\mathrm{Me})(\mathrm{Xyl})\}(\mu-\mathrm{CO})(\mathrm{CO})\{\mathrm{NHC}\right.$ $\left.\left.\left(\mathrm{C} \equiv \mathrm{CC}_{6} \mathrm{H}_{4} \mathrm{Me}-4\right) \mathrm{CMe}_{3}\right\}(\mathrm{Cp})_{2}\right]\left[\mathrm{SO}_{3} \mathrm{CF}_{3}\right](8)$

A solution of $\mathrm{LiC} \equiv \mathrm{CC}_{6} \mathrm{H}_{4} \mathrm{Me}-4$, (freshly prepared from n-butyllithium and 4-ethynyltoluene $0.50 \mathrm{mmol}$ ) in THF $(10 \mathrm{~mL})$, was added to a stirred solution of $7 \mathrm{c}(320 \mathrm{mg}$, $0.47 \mathrm{mmol})$, in THF $(7 \mathrm{~mL})$, at $-30{ }^{\circ} \mathrm{C}$. The mixture was stirred for $15 \mathrm{~min}$ and the color changed to brownish-green. Then $\mathrm{HSO}_{3} \mathrm{CF}_{3}(0.045 \mathrm{~mL}, 0.51 \mathrm{mmol})$ was added dropwise and the mixture turned immediately dark yellow. The mixture was warmed to room temperature filtered on a celite pad. Solvent removal and chromatography on an alumina column, with a mixture of $\mathrm{THF}$ and $\mathrm{CH}_{3} \mathrm{CN}(1: 1 / \mathrm{v}: \mathrm{v})$ as eluent gave a brown band that was collected. Crystallization of $\mathbf{4 a}$ from $\mathrm{CH}_{2} \mathrm{Cl}_{2}$ layered with diethyl ether gave dark brown crystals (191 mg, 51\%).

Anal. Calcd for $\mathrm{C}_{37} \mathrm{H}_{39} \mathrm{~F}_{3} \mathrm{Fe}_{2} \mathrm{~N}_{2} \mathrm{O}_{5} \mathrm{~S}: \mathrm{C}, 56.07 ; \mathrm{H}, 4.96$. Found: C, 56.21; H, 5.01. IR (KBr pellets) $v_{\max } / \mathrm{cm}^{-1}: 3314$ $(\mathrm{N}-\mathrm{H}) ;\left(\mathrm{CH}_{2} \mathrm{Cl}_{2}\right): 2200 \mathrm{~m}(\mathrm{C} \equiv \mathrm{C}), 1977 \mathrm{vs}$ and $1817 \mathrm{~s}(\mathrm{CO})$. NMR $\delta_{\mathrm{H}}\left(\mathrm{CDCl}_{3}\right): 7.78-7.31\left(7 \mathrm{H}, \mathrm{m}, \mathrm{Me}_{2} \mathrm{C}_{6} \mathrm{H}_{3}\right.$ and $\left.\mathrm{MeC}_{6} H_{4}\right), 6.12(1 \mathrm{H}, \mathrm{s}, \mathrm{N}-\mathrm{H}), 5.06,4.44(10 \mathrm{H}, \mathrm{s}, \mathrm{Cp}), 4.94$ (3 H, s, NMe), 2.71, $2.19\left(6 \mathrm{H}, \mathrm{s}, \mathrm{Me}_{2} \mathrm{C}_{6} \mathrm{H}_{3}\right), 2.48(3 \mathrm{H}, \mathrm{s}$, $\left.M e \mathrm{C}_{6} \mathrm{H}_{4}\right), 0.96\left(\mathrm{~s}, 9 \mathrm{H}, \mathrm{CMe}_{3}\right) . \delta_{\mathrm{C}}\left(\mathrm{CDCl}_{3}\right): 339.9(\mu-\mathrm{C})$, $263.9(\mu-\mathrm{CO}), 212.6(\mathrm{CO}), 186.7(\mathrm{~N} \equiv C), 148.4,141.8$ (ipso$\mathrm{Me}_{2} \mathrm{C}_{6} \mathrm{H}_{3}$ and ipso- $\left.\mathrm{MeC}_{6} \mathrm{H}_{3}\right) ; 133.2-128.9\left(\mathrm{Me}_{2} \mathrm{C}_{6} \mathrm{H}_{3}\right.$ and $\mathrm{MeC}_{6} \mathrm{H}_{3}$ ), 117.4, 107.1 (C $\left.\equiv \mathrm{C}\right), 88.2,88.0(\mathrm{Cp}), 53.8(\mathrm{NMe})$, 44.2, $26.6\left(\mathrm{CMe}_{3}\right), 21.8\left(\mathrm{MeC}_{6} \mathrm{H}_{4}\right)$, 18.6, $17.6\left(\mathrm{Me}_{2} \mathrm{C}_{6} \mathrm{H}_{3}\right)$.

\section{Acknowledgements}

We thank the Ministero dell'Universita' e della Ricerca Scientifica e Tecnologica (M.I.U.R.) (project: 'New strategies for the control of reactions: interactions of molecular fragments with metallic sites in unconventional species') and the University of Bologna ('Funds for Selected Research Topics') for financial support.

\section{References}

1. Muetterties, E. L.; Stein, J.; Chem. Rev. 1979, 19, 479; Rofer De Poorter, C. K. ; Chem. Rev. 1981, 81, 447; Maitlis, P.M.; Long, H.C.; Quyoum, R.; Turner, M. L.; Wang, Z. Q.; J. Chem. Soc. Chem. Commun. 1996, 1.

2. Turner, M. L.; Nyoman, M.; Mann, B. E.; Quyoum, R.; Long, H.C.; Maitlis, P. M.; J. Am. Chem. Soc. 2002, 124, 10456.
3. Albano, V. G.; Busetto, L.; Camiletti, C.; Castellari, C.; Monari, M.; Zanotti, V.; J. Chem. Soc., Dalton Trans. 1997, 4671; Albano, V. G.; Bordoni, S.; Busetto, L.; Camiletti, C.; Monari, M.; Palazzi, A, Prestopino, F.; Zanotti, V.; J. Chem. Soc., Dalton Trans. 1997, 4665.

4. Casey, C.P.; Fagan, P. J.; Day V. W.; J. Am. Chem. Soc. 1982, 104, 7360; Casey, C.P.; Meszaros,M.W.; Fagan, P. J.; Bly, R.K.; Marder, S.R.; Austin, E.A.; J. Am. Chem. Soc. 1982, 108, 4043; Casey, C.P.; Vosejpka, P.C.; Organometallics 1988, 7, 934.

5. Zanotti, V.; Bordoni, S.; Busetto, L.; Carlucci, L.; Palazzi, A.; Serra, R.; Albano, V.G.; Monari, M.; Prestopino, F.; Laschi, F.; Zanello. P.; Organometallics 1995, 14, 5232.

6. Cox, G.; Dowling, C.; Manning, A. R.; McArdle, P.; Cunningham, D.; J. Organomet. Chem. 1992, 438, 143; Albano, V.G.; Busetto, 1.; Castellari, C.; Monari, M.; Palazzi, A.; Zanotti, V.; J. Chem. Soc., Dalton Trans. 1993, 3661

7. Doherty, N. M.; Howard, J. A. K.; Knox, S. A. R.; Terril, N. J.; Yates, M. I.; J. Chem. Soc., Chem. Commun. 1989, 638; Fildes, J. M.; Knox, S. A. R.; Orpen, G.; Turner, M. L.; Yates, M. I.; J. Chem. Soc., Chem. Commun. 1989, 1680; Akita, M.; Hua, R.; Knox, S. A. R.; Moro-oka, Y.; Nakanishi, S.; Yates, M. I.; J. Organomet. Chem. 1998, 569, 71; Akita, M.; Hua, R.; Knox, S. A. R.; Moro-oka, Y.; Nakanishi, S.; Yates, M. I.; Chem. Commun. 1997, 51.

8. Albano, V.G.; Busetto, L.; Monari, M.; Zanotti. V.; J. Organomet. Chem. 2000, 606, 163.

9. Storhoff, B. N.; Lewis Jr., H. C.; Coord. Chem. Rev. 1977, 23, 1; Endres, H. In Comprehensive Coordination Chemistry; Wilkinson, G.; Gillard, R. D.; McCleverty J. A., eds., Pergamon: Oxford, 1987, 261, vol. 2.

10. Boss, K.; Cox, M.G.; Dowling, C.; Manning, A.R.; J. Organomet. Chem. 2000, 612, 18.

11. Cox, G.; Dowling, C.; Manning, A. R.; McArdle, P.; Cunningham, D.; J. Organomet. Chem. 1992, 438, 143.

12. Albano, V.G.; Busetto, L.; Marchetti, F.; Monari, M.; Zanotti. V.; J. Organomet. Chem. 2002, 649, 64.

13. Murahashi, S.I.; Naota, T.; Taki, H.; Mizuno, M.; Takaya, H.; Komiya, S.; Mizuho, Y.; Oyasato, N.; Hiraoka, M.; Hirano, M.; Fukuoka, A.; J. Am. Chem. Soc. 1995, 117, 12436; Trost, B. M.; Toste, F. D.; Pinkerton, A. B.; Chem. Rev. 2001, 101, 2067.

14. Sterenberg, B. T.; Hilts, R. W.; Moro, G.; McDonald, R.; Cowie, M.; J. Am. Chem. Soc. 1995, 117, 245.

15. Boss, K.; Dowling, C.; Manning, A. R.; J. Organomet. Chem. 1996, 509, 197.

16. Busetto, L.; Zanotti, V.; Albano, V. G. ; Monari, M.; Castellari, C.; Gazz. Chim. Ital. 1993, 123, 703.

17. Castarlenas, R.; Esteruelas, M.A.; Oñate, E.; Organometallics 2001, 20, 3229 and references therein. 
18. Michelin, R. A.; Mozzon, M.; Bertani, R.; Coord. Chem. Rev. 1996, 147, 299; Garnovskii, D. A.; Kukushkin, V. Y.; Haukka, M.; Wagner, G.;. Pombeiro, A. J. L.; J. Chem. Soc., Dalton Trans. 2001560 and references therein; Bertani, R.; Catanese, D.; Michelin, R. A.; Mozzon, M.; Bandoli, G.; Dolmella, A.; Inorg. Chem. Commun. 2000, 3, 16; Chin, C. S.; Chong, D.; Lee, B.; Jeong, H.; Wong, G.; Do, Y.; Park, Y. J.; Organometallics 2000, 19, 638.
19. Kukuskin, V.Y.; Pombeiro, A.J.L.; Chem. Rev. 2002, 102, 1771; Feng, S. G.; Templeton, J. L.; Organometallics 1992, 11, 1295; Cucciolito, M.E.; De Felice, V.; Giordano, F.; Orabona, I.; Ruffo, F.; Eur. J. Inorg. Chem. 2001, 3095; Yeh, W. Y.; Ting, C. S.; Peng, S. M.; Lee, G. H.; Organometallics 1995, 14, 1417.

Received: December 4, 2002 Published on the web: July 11, 2003 